\title{
Miocene quartz sands redeposited on subaqueous and alluvial fans during the Saalian: Interpretation of the depositional scenario at Ujście, western Poland
}

\author{
Mateusz Mleczak*, Małgorzata Pisarska-Jamroży \\ Institute of Geology, Adam Mickiewicz University, B. Krygowskiego 12, 61-680 Poznań, Poland; \\ *corresponding author, e-mail: mateusz.mleczak@amu.edu.pl
}

\begin{abstract}
The 14-m-thick sandy succession at Ujście in western Poland formed during the Odranian stadial of the Saalian glaciation, is exceptional in being very well sorted, almost mono-fractional (fine-grained sands) and mono-mineral (mainly quartz grains) and in lacking Scandinavian erratics. The lower sequence (5 metres in thickness) consists of three stacked packages of clinoforms (inclined cross-stratified sands) and is interpreted as having been deposited on a subaqueous fan in a shallow lake during two phases of rising water levels. The upper sand (9 metres in thickness) with (sub) horizontal stratification was redeposited on a subaerial alluvial fan. Distinctive distributary channels that occur in the uppermost part of the subaqueous fan and in the lowermost portion of the alluvial fan may indicate a change in sedimentation style from subaqueous to subaerial. Moreover, the subaerial position of the fan supports the presence of ice-wedge casts that developed under periglacial conditions in the upper part of alluvial fan. The results of granulometric analysis, rounding and frosting of grains and mineral analysis indicate that the sands are derived from Gorzów Formation of Early Miocene age. The only feasible explanation is that the 14-m-thick unit must have been redeposited during the Saalian glaciation.
\end{abstract}

Key words: proglacial lake, distributary channels, sandy clinothems, Odranian stadial

\section{Introduction}

Shape and size of depositional bodies such as alluvial fans, subaqueous fans or deltas accumulated in the lacustrine environment depend on the morphology of the basin, changes of base level, the amount and size of grains supplied to the basin by rivers, the depth of the lake or basin, stream power, climatic conditions and more (compare Boothroyd \& Nummedal, 1978; Nilsen, 1985; Rachocki \& Church, 1990; Orton \& Reading, 1993; Blair \& McPherson, 1994; Miall, 1996; Blair, 1999; Harvey et al., 1999; Salamon \& Wójcik, 2010; Zielinski, 2014; Zieliński et al., 2016). The majority of Pleistocene lacustrine subaqueous fans and deltas have been described from proglacial environments (e.g., Kostaschuk \& Smith, 1983; Billi et al., 1991; Lunkka \& Alhonen, 1996; Lemons \& Chan, 1999; Bennett et al., 2000; Gruszka et al., 2004; Lønne \& Nemec, 2004; Hornung et al., 2007; Winsemann et al., 2007; Clemmensen \& Houmark-Nielsen, 2008; Winsemann et al., 2009; Ravier et al., 2014; Woźniak \& Pisarska-Jamroży, 2018; Woźniak et al., 2018). Such environments explain the coarse-grained or generally polymodal textural features of sediments. In this context, the origin of the present near-unimodal, fine-grained sediment deposited during the Saalian glaciation appears exceptional. The succession studied at Ujście comprises 14 metres of well-sorted, unimodal, fine-grained quartz sands, enriched only locally in fine-grained gravels and armoured mud balls. 
The aim of the present paper is fourfold: first, to describe textural and structural features of the sandy succession at Ujście; secondly, to explain sediment genesis in this 14-m-thick succession; thirdly, to identify depositional conditions during erosion of Miocene-aged strata and subsequent transport and redeposition, and lastly, to illustrate features which allow to distinguish between subaqueous and subaerial fans.

\section{Geological setting}

The Ujście site (co-ordinates $53^{\circ} 02^{\prime} 40^{\prime \prime} \mathrm{N}, 16^{\circ} 41^{\prime} 41^{\prime \prime} \mathrm{E}$ ) is located along the southern margin of the Ujście Basin (= Piła-Ujście Basin; Galon, 1961) near the mouth of the River Gwda towards the Torun-Eberswalde ice-marginal valley in northwestern Poland
(Fig. 1). This ice-marginal valley drained meltwater from proglacial streams and water from extraglacial areas during the maximum extent of the Pomeranian phase (16-17 ka BP; Marks, 2012; Pisarska-Jamroży, 2015) and the Angermünde-Chojna subphase

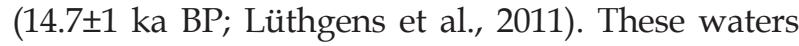
eroded the southern margin of the Torun-Eberswalde ice-marginal valley, where strata of Saalian to Weichselian age are excavated (MIS 8-MIS 2; Pisarska-Jamroży et al., 2019a). Today, the Ujście Basin and adjacent river valleys are occupied by Holocene peat areas and fluvial strata (Fig. 1). Locally, within eroded slopes of the ice-marginal valley, strata of $\mathrm{Mi}$ ocene age that directly underlie those formed during Pleistocene glaciations, are exposed (Bartczak, 2006).

The Ujście site has featured in numerous publications that have dealt mainly with lithostratigraphy (Kasprzak \& Kozarski, 1985; Kozarski \&

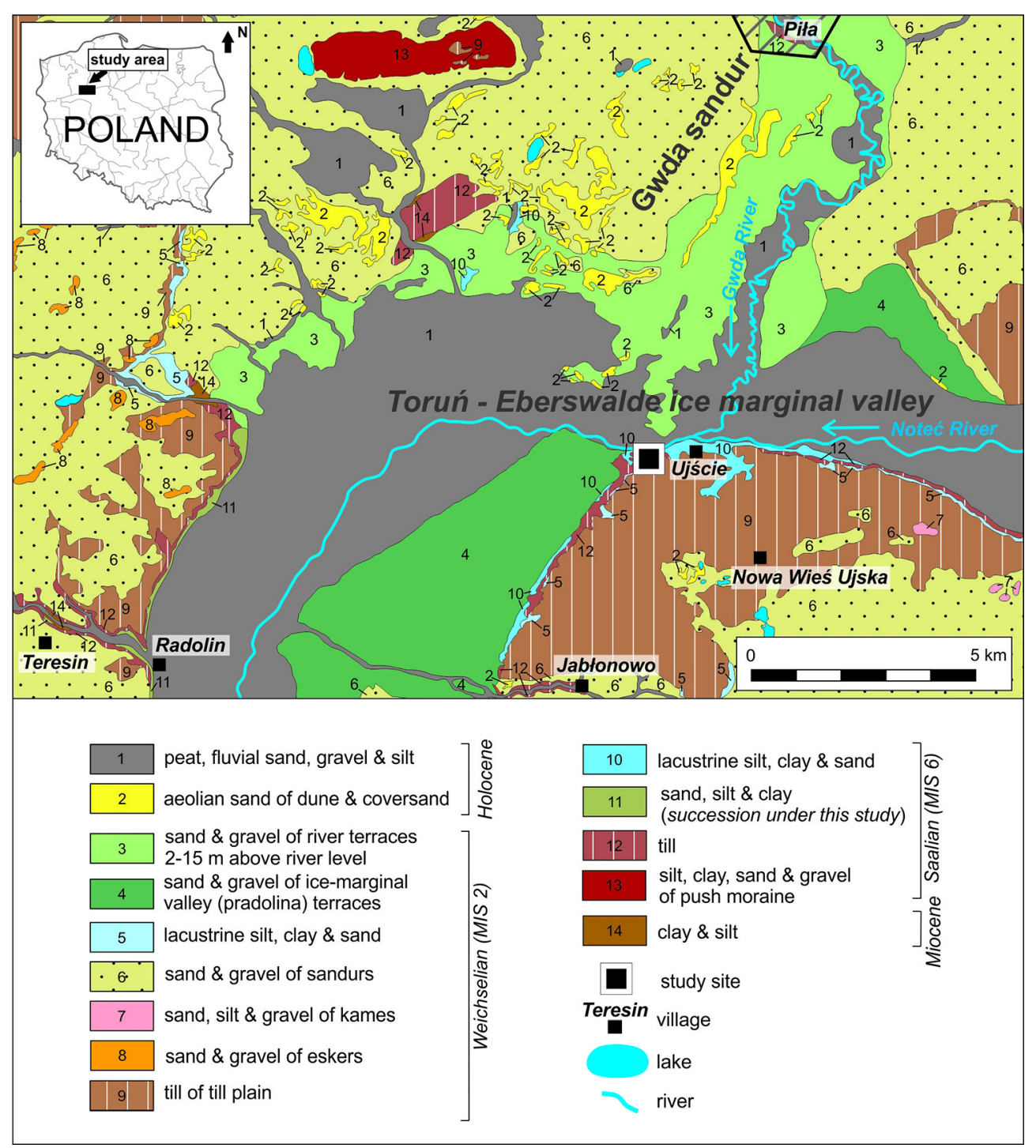

Fig. 1. The study site at Ujście and its geological setting (modified from Bartczak, 2006) 
Nowaczyk, 1985; Kozarski \& Kasprzak, 1987; Böse \& Górska, 1995; Petterson, 1997; Kenig, 2004; Pisarska-Jamroży et al., 2019a), but the origin of the sandy succession in the lowermost part of the 35-m-thick succession at Ujście has never been firmly established. However, Bartczak (2006) did mention that this sandy succession (fine-grained sands and silty sands with intercalations of vary-grained sands and fines of silty- and clayey-fraction) had a 'glaciolacustrine/glaciofluvial origin' and that the sands passed upwards into silty sediments in the vicinity of Radolin and Teresin and into silty/clayey strata near Nowa Wieś Ujska and Jabłonowo (Fig. 1).
Nowadays, the quartz grains (>90\%) with inclusions of biotite, muscovite, rutile and zircon (see Bartczak, 2006), commonly referred to as 'glass sands', are used by the glass production firm Ardagh Glass S.A. for green beer bottles, e.g. Budweiser, Heineken and Carlsberg.

\section{Methods}

Textural and structural features of strata were described using a lithofacies code (Table 1) following Zieliński and Pisarska-Jamroży (2012) and, for the
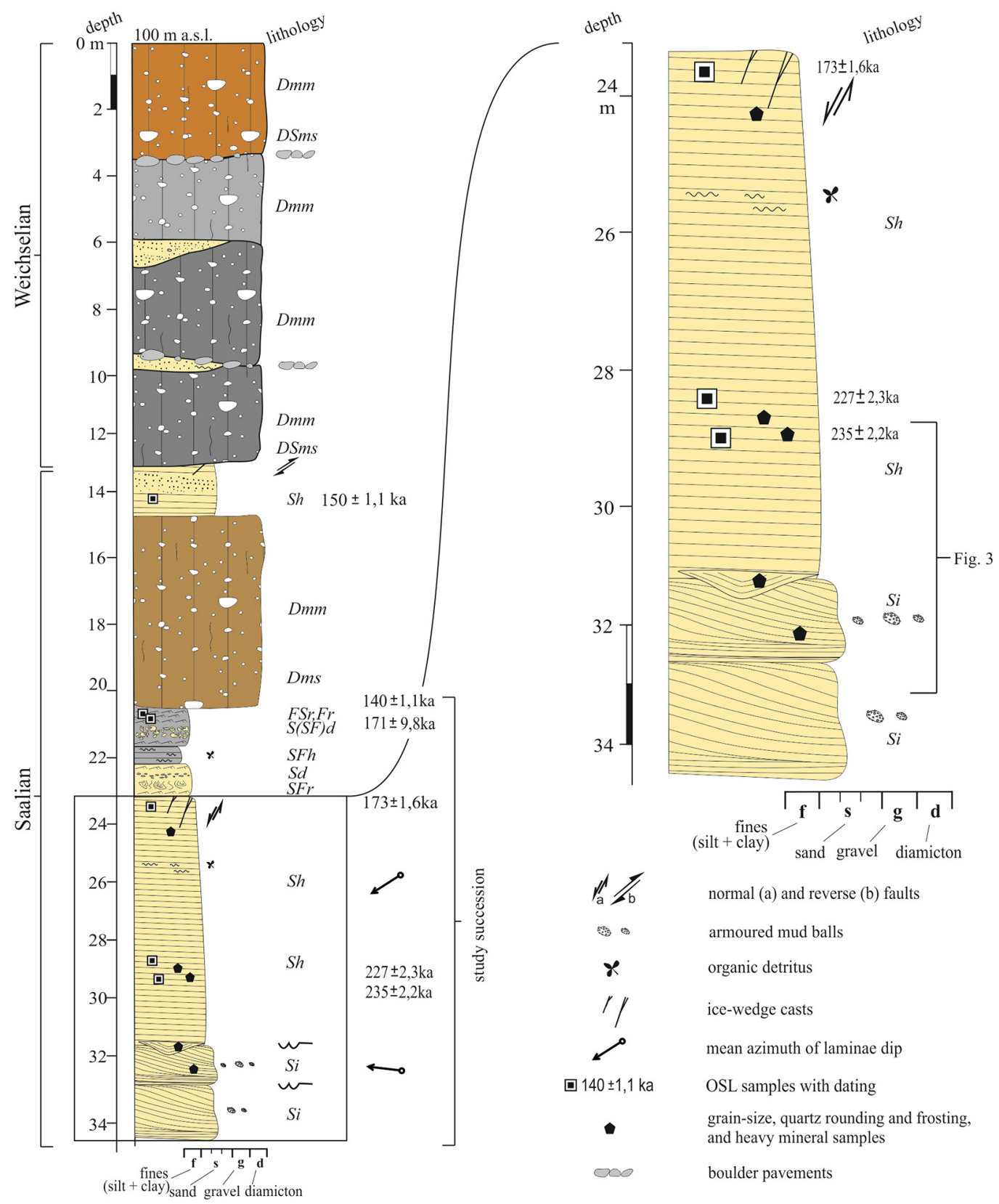

Fig. 2. Sedimentary log for the Ujście site (based on Mleczak et al., 2017). For details see Table 1 
Table 1. Textural and structural symbols of lithofacies code used in the present study

\begin{tabular}{|c|c|c|c|}
\hline \multirow{2}{*}{$\begin{array}{l}\text { Litho- } \\
\text { facies }\end{array}$} & \multirow[t]{2}{*}{ Main features of lithofacies } & \multirow[t]{2}{*}{ Interpretation } & textural symbols \\
\hline & & & diamicton \\
\hline \multirow[t]{2}{*}{ Si } & \multirow{2}{*}{$\begin{array}{l}\text { fine sand } \\
\text { low angle }\left(12-17^{\circ}\right) \text { sigmoidal cross-stratified }\end{array}$} & \multirow{2}{*}{$\begin{array}{l}\text { low-angle prograda- } \\
\text { tion front of delta }\end{array}$} & sand \\
\hline & & & SF sand with fines \\
\hline \multirow[t]{3}{*}{ Sh } & \multirow{3}{*}{$\begin{array}{l}\text { very fine and fine sand } \\
\text { sub-horizontal stratified } \\
\text { sheet-like layers }\end{array}$} & \multirow{3}{*}{$\begin{array}{l}\text { subaqueous, sandy, } \\
\text { very shallow sheet- } \\
\text { flow }\end{array}$} & sandy fines \\
\hline & & & fines (silt + clay) \\
\hline & & & structural symbols \\
\hline \multirow[t]{3}{*}{ Se } & \multirow{3}{*}{$\begin{array}{l}\text { fine sand } \\
\text { massive or cross-stratified } \\
\text { erosional base }\end{array}$} & \multirow[t]{3}{*}{ erosional scour fill } & massive structure \\
\hline & & & horizontal lamination \\
\hline & & & ripple cross-lamination \\
\hline \multirow{2}{*}{$\begin{array}{l}\text { SFr, FSr, } \\
\text { Fr }\end{array}$} & \multirow{2}{*}{$\begin{array}{l}\text { very fine sand and fines } \\
\text { sheet-like layers }\end{array}$} & \multirow{2}{*}{$\begin{array}{l}\text { weak currents in near- } \\
\text { ly stagnant water }\end{array}$} & inclined stratification \\
\hline & & & deformed structure \\
\hline \multirow[t]{3}{*}{$\mathrm{Sd}$} & \multirow{3}{*}{$\begin{array}{l}\text { two horizots of deformed sediment } \\
\text { load casts pseudonodules and flame struc- } \\
\text { tures }\end{array}$} & \multirow{3}{*}{$\begin{array}{l}\text { deformation by lique- } \\
\text { faction }\end{array}$} & $e \quad$ erosional scour fill \\
\hline & & & structural symbols for diamictons \\
\hline & & & $m m$ matrix-supported, massive \\
\hline S(SF)d & $\begin{array}{l}\text { two breccia layers } \\
\text { numerous soft-sediment clasts }\end{array}$ & mudflow & ms matrix-supported, stratified \\
\hline SFh & $\begin{array}{l}\text { very fine sand } \\
\text { sheet-like layers }\end{array}$ & suspension fallout & \\
\hline $\begin{array}{l}\text { Dmm/ } \\
\text { Dms }\end{array}$ & $\begin{array}{l}\text { massive diamicton, lower part stratified } \\
\text { matrix-supported } \\
\text { numerous faults, drag folds and cleavage in } \\
\text { lower part } \\
\text { extended clasts of unconsolidated sediments }\end{array}$ & glacial deposits & \\
\hline
\end{tabular}
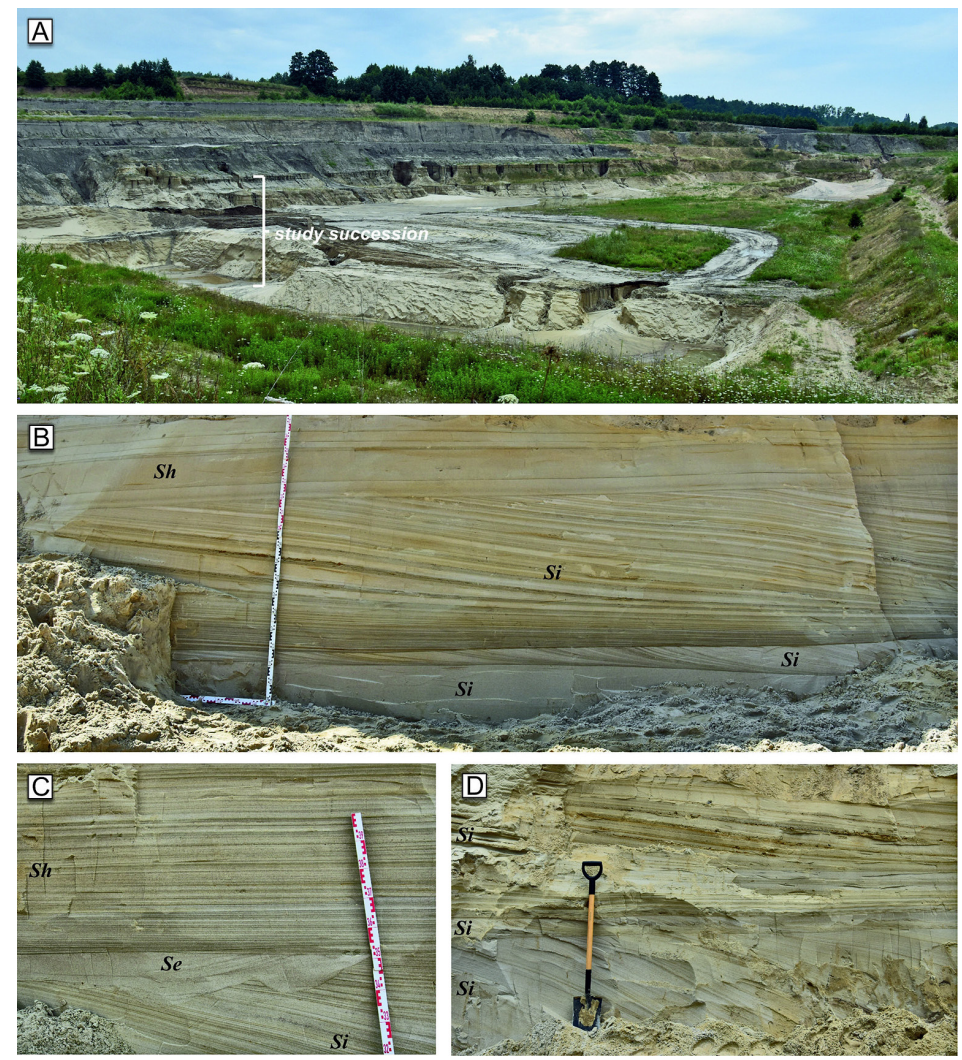

Fig. 3. Sedimentary succession at Ujście: A - Vertical and lateral continuity of sediments; B - Three clinoforms of subaqueous fans (lithofacies $\mathrm{Si}$ ) and lower part of the alluvial fan (lithofacies Sh); C - Distributary channels (lithofacies $\mathrm{Se}$ ) occurring in the uppermost set of lithofacies Si; D - More distal part of three clinoforms of subaqueous fans (presented in photograph C) 
diamictons, following Krüger and Kjær (1999). The term 'fines' used in the present paper, refers to clay and silt together. Grain size indication follows the Udden-Wentworth scale (Udden, 1914; Wentworth, 1922), while grain size parameters such as median grain size, sorting and skewness, were calculated using the Folk and Ward method (Folk \& Ward, 1957). The results obtained from grain size analyses are presented in a Passega C-M diagram, where the values of the first percentile $(C)$ are plotted against the median grain diameter $(\mathrm{M})$.

Nineteen samples for grain size and five samples for quartz grain rounding and frosting (following Cailleux, 1942; Mycielska-Dowgiałło \& Woronko, 1998; Woronko et al., 2015) and heavy mineral composition (following Marcinkowski \& Mycielska-Dowgiałło, 2013) were analysed. The samples were taken from the entire extent of the outcrop.

Furthermore, five samples were dated by optically stimulated luminescence (OSL) - two from the lower and three from the upper part of sandy succession analysed (Fig. 2). The OSL measurements were performed at the GADAM Gliwice Luminescence Laboratory using the standard multi-grain aliquots method. Equivalent doses of samples were determined using the single-aliquot regenerative-dose (SAR) protocol (e.g., Thrasher et al., 2009).

\section{Sedimentary succession}

At Ujście, the 14-m-thick sandy sequence forms the lower portion of a 35-m-thick sedimentary succession (Figs 2,3A). The uppermost part of the Saalianand Weichselian-aged sediments have previously been described and interpreted in detail (see references below), but the subject of the present study is the lowermost sandy succession, which comprises three lithofacies: $S i$ - sands with inclined stratification, $S h$ - horizontally stratified sands and $S e$ sands with scour fills (Figs 2, 3B-D, 4A).
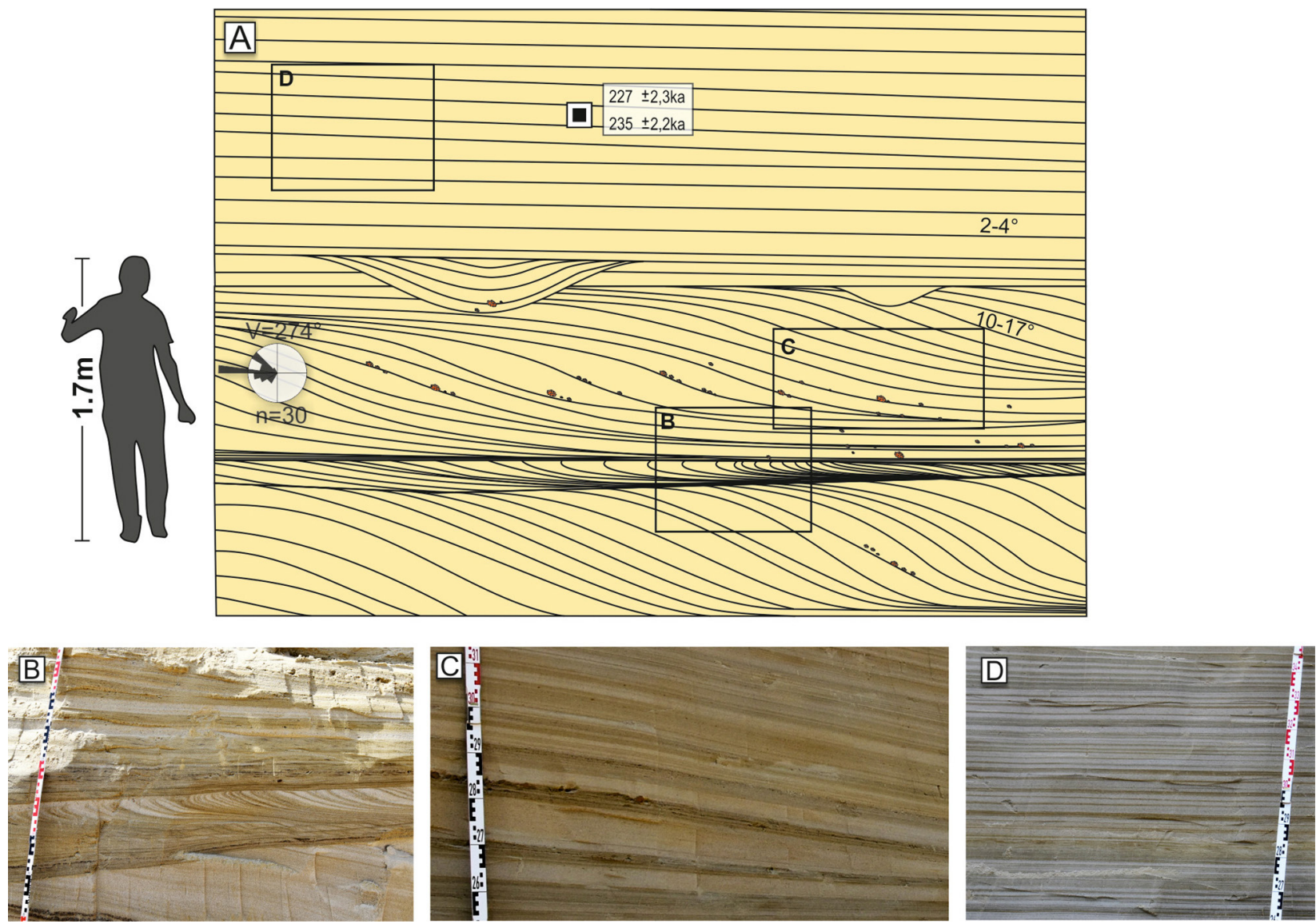

Fig. 4. Sandy sediments occurring in the lowermost part at Ujście: A - Schematic vertical and lateral distribution of sediments in the sandy succession; B - Middle sandy set with inclined tangential stratification and bent beds in the upper part (see centre of photograph); C - Upper set of sands with inclined sigmoidal stratification; D - (Sub)horizontally-stratified sands of alluvial fan. For details see Table 1 


\subsection{Description}

\subsubsection{Textural features of lithofacies}

The three lithofacies distinguished here are characterised by almost identical textural features (Fig. 5): grain size distribution indicates well-sorted, mainly fine-grained, sandy sediment, with identical heavy mineral spectra. Grains have mainly mat surfaces and are rounded. However, subtle differences are described below.

Lithofacies Si comprises between 95 and 100\% well-sorted, fine-grained sand. Individual beds of this lithofacies are delineated by colour (Figs 4C, $5)$. The lighter beds consist of mostly fine (53-65\%) and medium sand (32-42\%), with an admixture of very fine sand and fines $(1-2 \%)$, as well as coarse sand (up to $1 \%$ ). Statistical parameters of grain size distribution in the lighter-coloured beds are as follows: mean grain size $0.189 \mathrm{~mm}$, moderately well sorted (0.508) and very coarse skewed (-0.473). In contrast, the darker-coloured beds contain mainly fine $(60-61 \%)$, very fine (12-25\%) and medium sand (7-16\%), with an admixture of fines (2.5-5.5\%) and coarse sand (1.5-9\%). These beds are characterised by a mean grain size of $0.152 \mathrm{~mm}$, moderately good sorting (0.677) and are fine to very coarse skewed (from 0.165 to -0.373 ). The Passega diagram shows that grains from the lighter-coloured beds are grouped in section $Q$, while those from the darker-coloured beds are distributed over two sections, $Q$ and $P$ (see Fig. 6).

In its lower portion, lithofacies Sh consists of $97-100 \%$ of sand, mainly fine and very fine grained (64-84\%), with an admixture of medium-grained

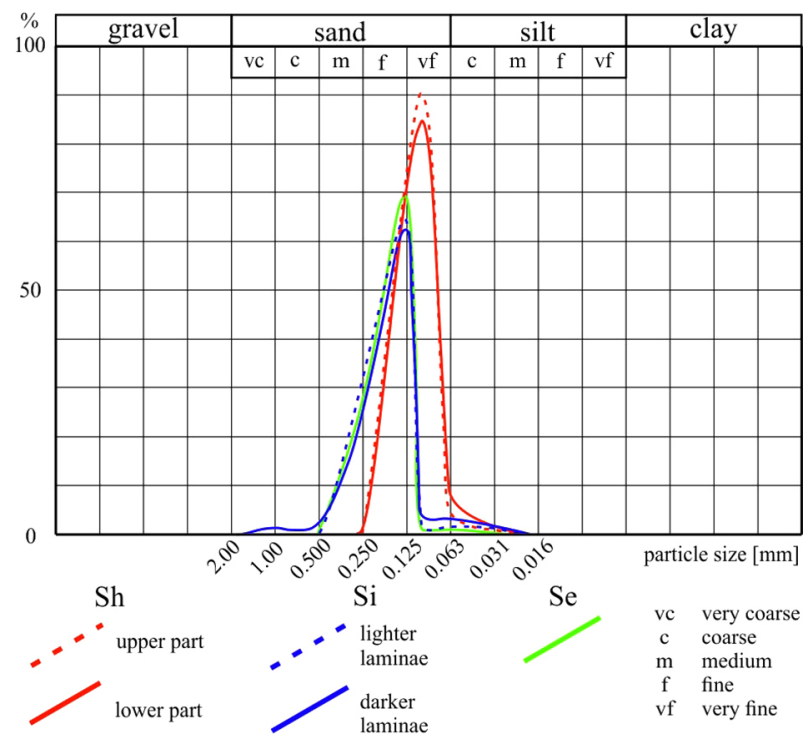

Fig. 5. Mean grain size composition of sandy lithofacies Sh, Si and Se at Ujście

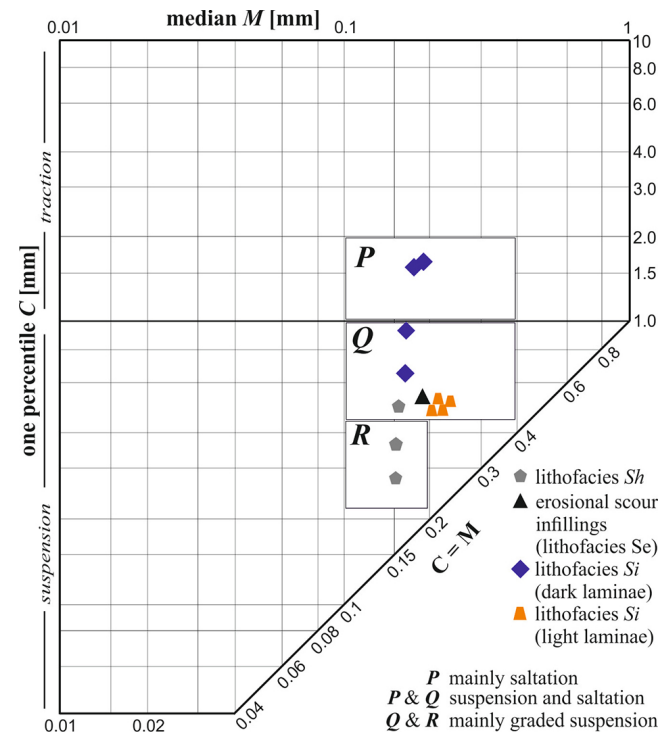

Fig. 6. Types of grain transport in sandy lithofacies at Ujście according to the Passega diagram (based on Passega, 1964; Zieliński, 2014)

sand (14-32\%) and silt (up to 3\%). These deposits is characterised by a mean grain size of $0.135 \mathrm{~mm}$, moderately good sorting (0.528) and a symmetrical skewness $(-0.06)$. The upper part of lithofacies Sh contains $98-99 \%$ fine and very fine sand and a small amount of silt (1-2\%). Statistical parameters of grain size distribution in this part are as follows: mean grain size of $0.132 \mathrm{~mm}$, very good sorting (0.322) and a fine skewness $(0.163)$. The grains are distributed over two sections, $R$ and $Q$, in the Passega diagram (Fig. 6).

Lithofacies Se comprises $99-100 \%$ sand, mainly fine grained (about 70\%), with an admixture of medium-grained sand (about 28\%) and very fine

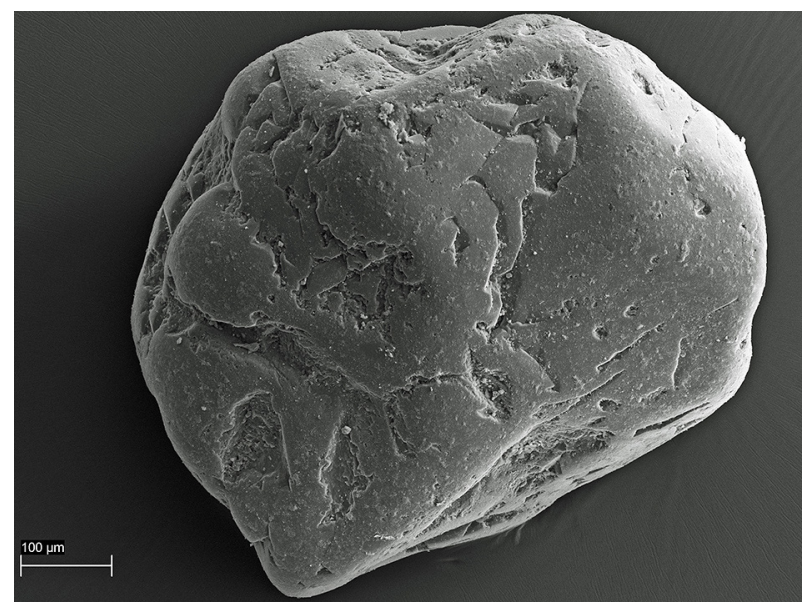

Fig. 7. SEM micrograph of the surface of a sand-sized quartz grain (from lithofacies Sh at Ujście) derived from a beach environment 
sand and fines (up to $4 \%$ ). Statistical parameters of grain size distribution within this lithofacies are as follows: mean grain size of $0.183 \mathrm{~mm}$, good sorting $(0.492)$ and a very coarse skewness $(-0.523)$. The grains of lithofacies $\mathrm{Se}$ occur in section $\mathrm{Q}$ of the Passega diagram (Fig. 6).

The majority of sand-sized quartz grains in lithofacies $S i$ and Sh are mat $(83 \%$ and $61-77 \%$, respectively; see Fig. 7). In lithofacies Si, quartz grains are mainly moderately subrounded and moderately angular (35\% and 31\%, respectively) and rounded (25\%), while in lithofacies Sh the majority are moderately angular (33\%) and moderately subrounded $(27 \%)$ and rounded $(26 \%)$.

Heavy mineral spectra in the sandy succession indicate a predominance of epidote $(19 \%)$, tourmaline $(17 \%)$, garnets $(13 \%)$, staurolite $(10 \%)$, amphibole $(9.5 \%)$ and kyanite $(5 \%)$.

\subsubsection{Structural features of lithofacies}

Lithofacies Si has three sets: lower, middle and upper (Figs 3D, 4A, B). The lower one is at least $1 \mathrm{~m}$ thick; the lower was not reached in the excavation. The middle set has a maximum thickness of $0.7 \mathrm{~m}$, which decreases northwards (Fig. 3D). The upper $S i$ set is up to $1.6 \mathrm{~m}$ thick (Fig. 4B). Boundaries between sets are well marked and erosional (Fig. 4A, B). The laminae of all sets have a sigmoidal shape and dip between 14 and $27^{\circ}$ westwards in the lower sets and between 10 and $17^{\circ}$ westwards in the upper. However, the angle of inclination decreases in the lower and upper parts of sets (Fig. 8A). A tangential shape of laminae occurs only locally in the middle set where they are deformed; see Figure $4 \mathrm{~B}$ that shows laminae bending in the upper part of the set. Furthermore, numerous mud balls, 1 to $7 \mathrm{~cm}$ in diameter, armoured by sand and fine gravel grains (Figs 4A, 8C) are clustered mainly in the lower, less-inclined part of sets. Organic detritus occurs also in some beds.

Lithofacies Sh is 9 metres thick (Figs 2, 4A, D). The lower and upper boundaries are well marked. However, the lower is erosional, the upper depositional. The parallel-stratified sands are inclined under a small angle $\left(2-4^{\circ}\right)$ towards the south, southwest and west, and are referred to as (sub) horizontally stratified. In the upper part of lithofacies Sh occur ice-wedge casts which reach up to $1.2 \mathrm{~m}$ in height (Fig. 8B). The width of these casts increases from a few millimetres at the base to $15-20 \mathrm{~cm}$ in the uppermost part (Fig. 8B). Close to the ice-wedge casts, in the upper part of the succession, normal faults, offsets and flexures of several centimetres occur (Fig. 8B). Furthermore, organic detritus is visible in the top part of the sands.

The trough cross-stratified lithofacies $S e$ is cut in the upper part of lithofacies $S i$ and in the lower part of lithofacies Sh (Figs 3C and 4A). The lower and upper boundaries of troughs are sharp and erosional. The internal structure of troughs is massive or cross stratified. Furthermore, armoured mud balls (up to $12 \mathrm{~cm}$ in diameter; Fig. 8D) were also observed within lithofacies $S e$.
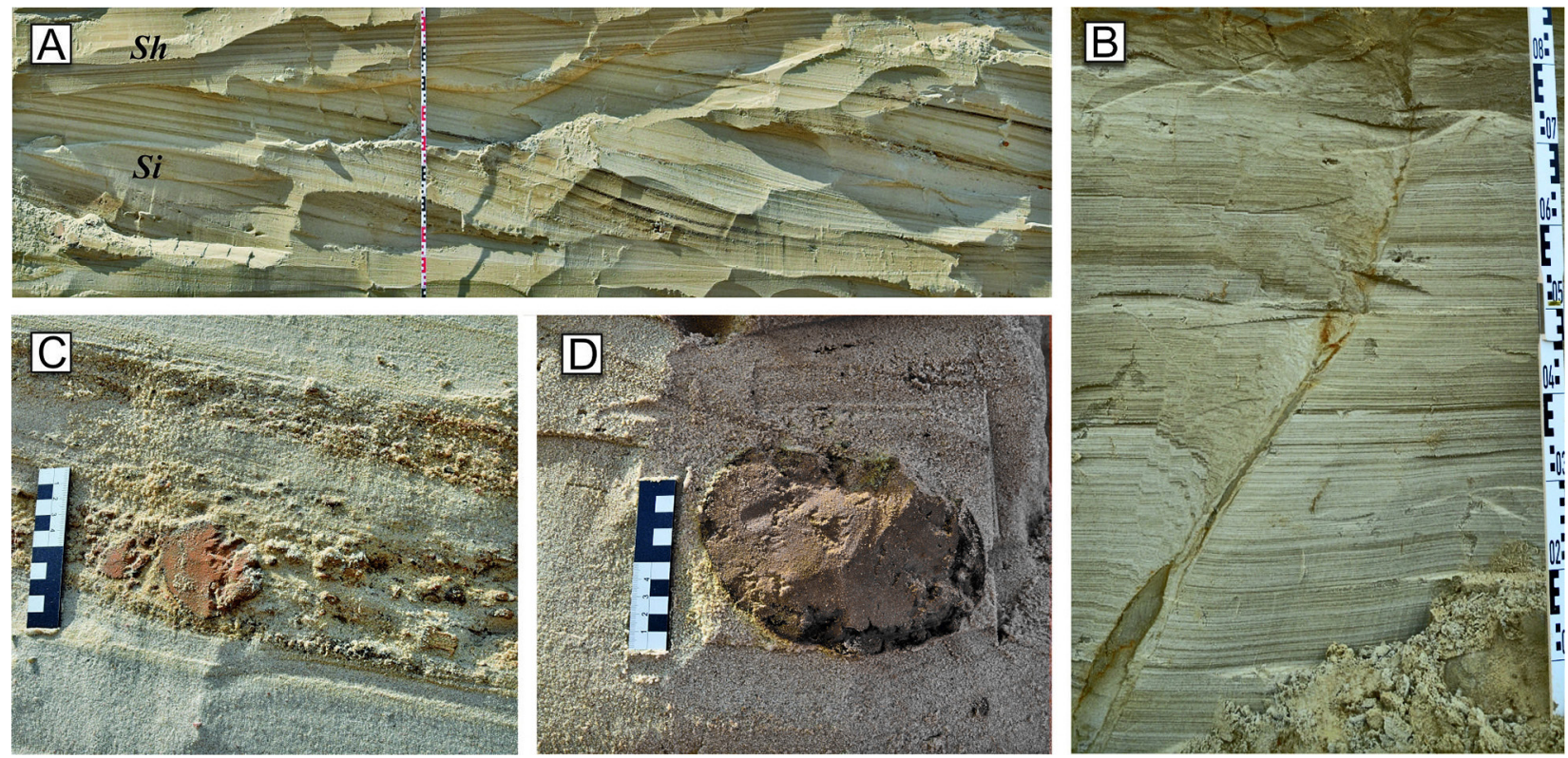

Fig. 8. Some structures within the sandy succession at Ujście: A - Sigmoidal-shaped beds in upper lithofacies $S i$, in the upper part of the photograph - lithofacies Sh of alluvial fan; B - Ice-wedge cast in upper part of alluvial fan (lithofacies Sh) with accompanying small-scale faults and flexures; C - Armoured mud balls in the upper set of lithofacies $\mathrm{Si}$; D - The largest armoured mud balls in the massive infill of a distributary channel (lithofacies $S e$ ) 


\subsection{Interpretation}

The sands in three clinoform lithofacies were deposited under similar, yet slightly changing depositional conditions (for details, see below). The grains in the lighter-coloured laminae of lithofacies $S i$ were transported by graded suspension, those in the darker-coloured laminae by a combination of saltation and graded suspension. This may indicate a cyclic change in flow dynamics. Grains in lithofacies $S h$ were deposited mostly from graded suspension. The good sorting of sandy sediments in the entire succession and mat surface of grains may suggest beach reworking (see Fig. 7). The heavy mineral spectra show the same source of sediments by evidence of resistant heavy minerals, such as epidote, tourmaline, garnets and staurolite that are similar to a known source.

The sets of lithofacies Si represent three clinoform bodies laid down as a subaqueous lacustrine fan. The sigmoidal shape of the lamination of lithofacies $S i$ is similar to the foreset subfacies of a delta. However, delta forms can only be identified if at least two (of three) parts of delta (i.e., bottomset, foreset and topset) occur. Moreover, the low angle of inclination of the depositional slope $\left(10-17^{\circ}\right)$ in the upper set, in comparison with the grain size of sediment (Kirkby, 1987; Zieliński, 2014) and types of grain transport, does not allow interpretation of the clinoforms as a typical delta foresets. For sandy foresets of a typical delta the dip angle should reach 20-30 (compare Kirkby, 1987; Zieliński, 2014), whereas in the succession studied this angle is 10$17^{\circ}$, and only occasionally exceeds $20^{\circ}$. Grain size analyses show that the sediments were distributed over subaqueous slopes by suspension and traction currents. This type of transport probably is a record of low-density turbidite currents that formed at river mouths by significant supply of fine-grained sediments. Increased flow energy on the fan slope caused an increase in proportion of suspension over bedload transport (Reineck \& Singh, 1980), which resulted in long-distance deposition recorded in the low-angle dip of laminae and the tangential shape of clinoforms.

The sets of Si clinoforms should not be treated as a bars of rivers because they do not meet the following criteria: (1) point-bar lithofacies should show a fining-up granulometry with muddy or even peat lithofacies of floodplain deposits at the top (e.g. Toonen et al., 2012; Moskalewicz et al., 2016), (2) point-bar Si lithofacies should pass into trough cross-stratified lithofacies of dunes or megaripples, deposited on the slope of a point bar or in the thalweg zone (e.g., Allen, 1964; Singh, 1977; Zieliński, 1998; Zieliński, 2014; Moskalewicz et al., 2016), (3) point-bar succession usually begins with channel-lag sheets or coarse-grained bedforms developed in the deepest part of a channel (e.g., McGowen \& Garner, 1970; Zieliński, 2014; Moskalewicz et al., 2016), (4) on point bars should occur ripple- or climbing ripple cross-laminated lithofacies with an orientation that is opposite to that of the direction of dip of the Si lithofacies (e.g., Zieliński, 2014; Sokołowski et al., 2019), (5) transverse bars with inclined foresets often formed in braided rivers usually coexist with trough cross-stratified lithofacies derived from megaripples (e.g., Ziel-

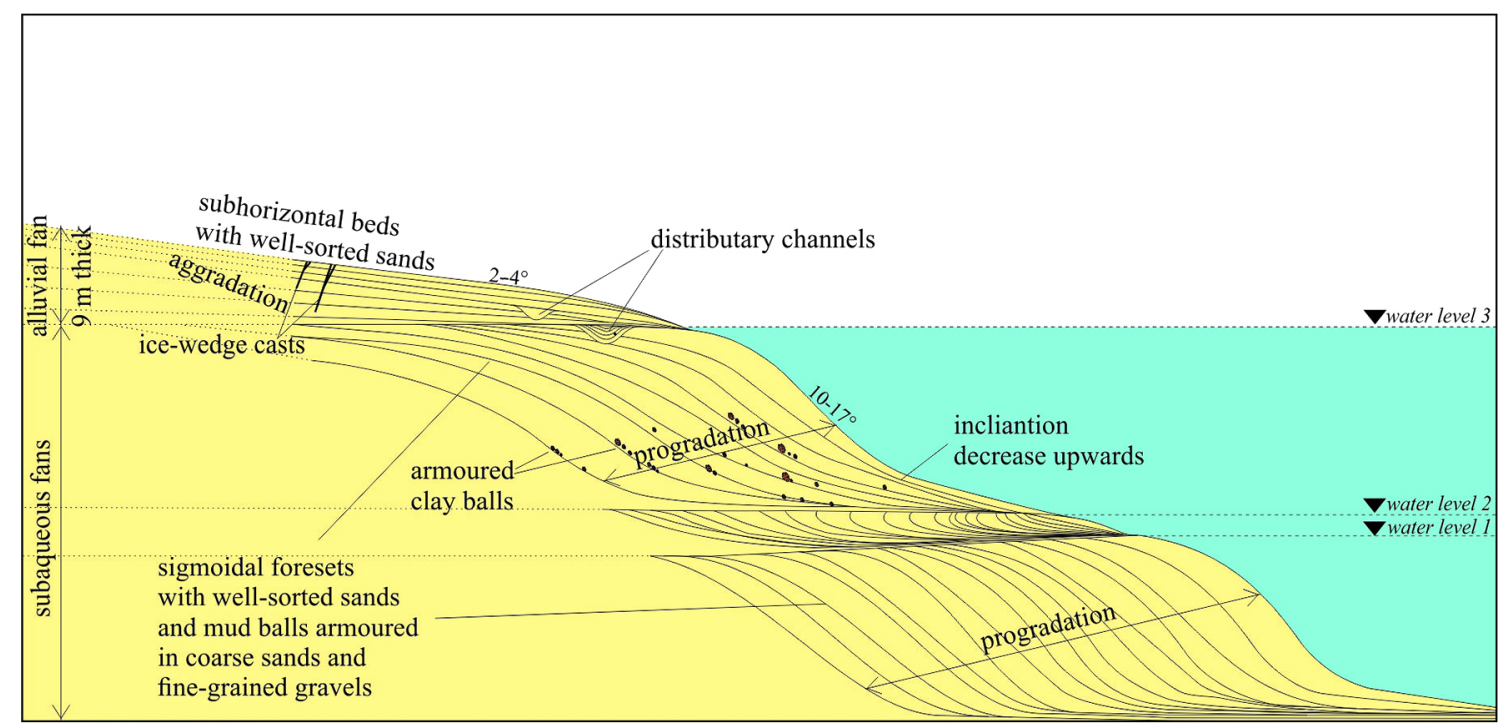

Fig. 9. Model and definition of subaqueous and alluvial fans of Miocene-aged sands at Ujście during the Odranian stadial of the Saalian glaciation 
iński, 1993; Pisarska-Jamroży, 2015), (6) at the top of transverse bars, ripple- or trough cross-stratified deposits of small bedforms (ripples or small-scale megaripples) migrating on the top of bars occur (e.g., Zieliński, 2014), (7) compound transverse bars characterised by several overlapping $S i$ sets require the co-existence of trough cross-stratified lithofacies (Sambrook Smith et al., 2006).

The sigmoidal shape of the clinoforms also indicates that progradation and aggradation processes were slow. The occurrence of three clinoform sets, separated by sharp and erosional surfaces, is linked to changes in the water level of the lake. The clinoforms were deposited on the low-angle slope of the sandy subaqueous fan in a quite shallow lake (Fig. 9). Afterwards, the thick (sub)horizontally-stratified lithofacies $S h$ - deposited by sheetfloods - formed. Lithofacies $S h$ is characterised by the same grain size as the underlying lithofacies Si, which may indicate the same sediment source. However, the depositional conditions had slightly changed. The thickness of 9 metres of these (sub)horizontal sands and their uniform granulometric composition indicate a period of stable depositional conditions. The thick lithofacies Sh probably is a record of river sheetfloods in the distal part of an alluvial fan.

We speculate that three clinothems (i.e., bodies with clinoform structure) of fans were deposited subaqueously, and the water level of the lake suddenly rose at least twice (up to water level 2 and 3 in Fig. 9), which was probably caused by lake outflow damming by e.g. blocks of ice. The lake was relatively shallow (up to a few metres in depth) and not extensive. The single distributary channels occurred only in the transition zone between uppermost subaqueous fan (upper set of lithofacies Si) and the lower part of the alluvial fan (lithofacies Sh), which likely indicates that this part was at least partially emerged and eroded by streams.

On the exposed part of the fan, ice-wedge casts evolved. They were formed in a thermal-contraction crack, and infilled by massive silty clay, probably from the overlying active layer. Afterwards the crack was rejuvenated and grew upwards in response to aggradation of the alluvial fan. The general narrowness of the wedge indicates that the sedimentation rate was relatively high (see French, 2017). The presence of ice-wedge casts that directly cut the upper part of the 9-m-thick alluvial fan suggests that the study area was subjected to periglacial processes. The small-scale faulting and flexures close to the ice-wedge casts formed as a result of consolidation and/or dewatering of previously water-laid sediments (see Pisarska-Jamroży et al., 2019b).

\section{Discussion}

Both lithostratigraphy and OSL ages suggest that the 14-m-thick sandy succession at Ujście was deposited during the Saalian glaciation. However, the mono-mineral, fine-grained spectrum of sandy sediments and their good sorting suggest an atypical source of sediments during glaciation.

\subsection{Possible sources of sandy sediments}

There are two possible sources of the sandy deposits at Ujście: glaciofluvial strata of Saalian age or eroded and redeposited older strata.

A characteristic feature of Pleistocene glacigenic deposits across Europe is the significant contribution of Scandinavian erratic rocks (e.g., Czubla et al., 2006; Górska-Zabielska, 2008; Czubla, 2015). In addition, sediments with high textural and architectural variability, resulting from unstable conditions of transport and deposition, are observed (e.g., Pisarska-Jamroży, 2006, 2008; Pisarska-Jamroży \& Zieliński, 2014). In contrast, in the case of Ujście, the 14-m-thick sandy succession is characterised by very well-sorted, mono-mineral, fine-grained sediment without Scandinavian erratic boulders and cobbles.

Very good sorting and the mono-mineral character of sediments are features that typically occur in Miocene-aged deposits that have previously been documented from the research area (Piwocki \& Ziembińska-Tworzydło, 1997; Bartczak, 2006). In the Ujście area, quartz sands of four Miocene formations are known: the Lower Miocene Gorzów Formation and the Middle Miocene Krajeńska, Adamów and Pawłowice formations (see Bartczak, 2006). These units comprise mostly grey, finegrained quartz sands with intercalations of brown fines (Bartczak, 2006) and have almost the same grain size distribution as sands at Ujście (e.g., finegrained sands account for 75-95\% in the Gorzów Formation; see Fig. 10). Moreover, the heavy mineral spectra of the sandy succession at Ujście and in the Gorzów Formation are similar (see Romanek, 2010; Fig. 10). Quartz sands of Miocene age have also been described from Mecklenburg-Vorpommern in northeast Germany as the Mölliner Schichten (formerly Quarzsand Gruppe or Quarzsand Horizont; see Piwocki \& Ziembińska-Tworzydło, 1997; Bartholomäus \& Granitzki, 2004; Schwietzer \& Niedermeyer, 2005). These are characterised by light grey-coloured fine-grained sands that contain 93-95\% of quartz grains (Zwahr, 2001).

The Miocene sands were deposited in a limno-fluvial environment on widely distributed allu- 

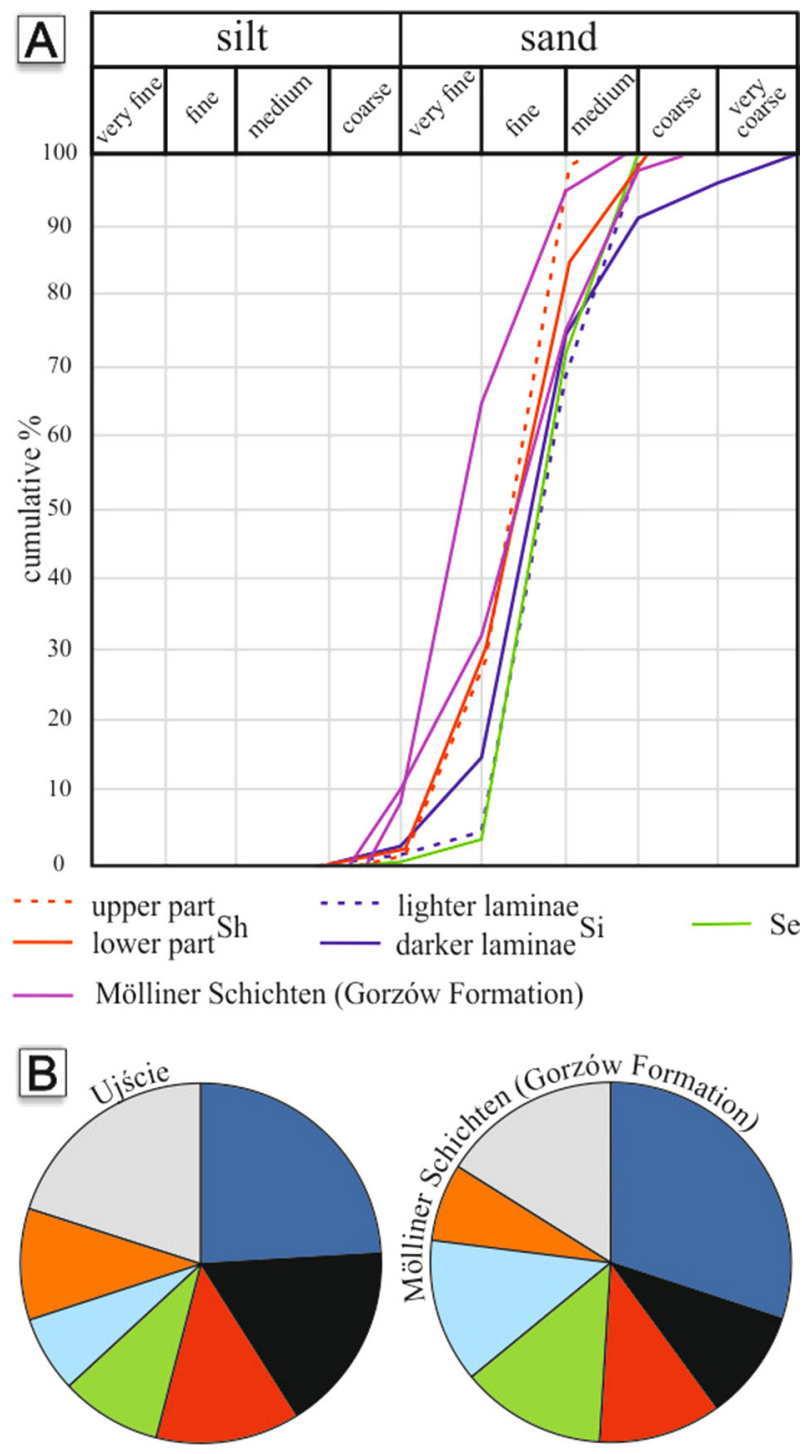

epidote group
tourmaline
garnets

amphibole

kyanite

staurolite

Fig. 10. Comparison of textural and mineralogical features of sandy sediments at Ujście and strata assigned to the Gorzów Formation (based on Schwietzer \& Niedermeyer, 2005; Romanek, 2010): A - Grain-size composition; B - Heavy mineral spectra

vial plains that came into being following the marine regression (Piwocki, 1978; Ciuk \& Pożaryska, 1982). The sediments were originally deposited as alluvial fans and deltas, most probably in a brackish environment. Such sediments were probably transported to the fluvial system and laid down on Miocene alluvial fans and deltas. Features of quartz grains from sandy sediments at Ujście seem to confirm this interpretation.

The Miocene formations in the vicinity of Ujście reach up to $51 \mathrm{~m}$ a.s.1. (Bartczak, 2006), whereas the sandy succession at Ujście analysed attains 77 $\mathrm{m}$ a.s.l. (Fig. 2), so we speculate, that Miocene sediments were eroded en block and transported as a raft by the Saalian ice-sheet. Afterwards, these sediments were washed out and redeposited by meltwaters on a subaqueous fan in a relatively shallow lake and on a subaerial fan.

\subsection{Timespan of deposition of the sandy succession}

The results of OSL dating for the lower part of the succession analysed indicate $227 \pm 2.2$ and $235 \pm 2.2 \mathrm{ka}$ BP (GdTL-2679 and GdTL-2680, respectively), i.e., the sandy succession studied must have formed prior to the Odranian stadial of the Saalian glaciation (MIS 8; 210-180 ka; see Marks et al., 2016). However, the upper part of the succession is dated as 173 \pm 1.6 BP (GdTL-2681), which may suggest deposition between the Odranian and Warthanian stadials, that is, during the Lublinian interglacial (MIS 7). However, the palynological content comprises Pinus, Corylus, Alnus and Ulmus and Miocene-aged Liquidambar, Nyssa and Ostrya (Woźniak, 2001, unpubl.). Taken together, these data suggest that the entire succession studied was laid down during the Odranian stadial of the Saalian glaciation.

\section{Conclusions}

The following conclusions can be drawn from thus study:

1. The 14-m-thick sandy succession at Ujście consists of almost unimodal, fine-grained sandy deposits that formed during the Odranian stadial of the Saalian glaciation (MIS 8),

2. The very good sorting of sediment and lack of Scandinavian erratic rocks within the sandy succession at Ujście are indicative of their Miocene age. The sand grains derived from the Lower Miocene Gorzów Formation (widely distributed in the vicinity of Ujście), which is characterised by a similar grain size composition and heavy mineral spectra,

3. The lower part of the sandy succession (lithofacies $\mathrm{Si}$ ) was deposited probably on subaqueous fans. A sequence of three stacked clinothems is separated by angular discordances and record two pulses of water level rise. The water rose in a relatively shallow proglacial lake, which was caused probably by lake outflow damming. Subsequently, the 9-m-thick alluvial fan was deposited. The presence of a few distributary channels 
in the uppermost part of the subaqueous fan and in the lower part of the subaerial fan may indicate that depositional bodies formed during the final phase of lake development. Moreover, the upper part of the alluvial fan was subjected to periglacial processes, as indicated by the presence of ice-wedge casts.

\section{Acknowledgments}

We thank Leszek Grochal, Janusz Hegyi and Paulina Frankiewicz (Ardagh Glass S.A., Ujście) for their kindness and permission to conduct geological investigations, Piotr Paweł Woźniak for discussion and Szymon Belzyt and Małgorzata Roman for field assistance. Basia Woronko took a SEM photograph of grains. Suggestions by anonymous reviewers and by Tomasz Zieliński have greatly helped to improve the manuscript, for which we are most grateful. This study has been financially supported by grants No. 2015/19/B/ST10/00661 and No. 2017/25/N/ST10/00322 from the National Science Centre Poland.

\section{References}

Allen, J.R.L., 1964. A review of the origin and characteristics of recent alluvial sediments. Sedimentology 5, 89-191.

Bartczak, E., 2006. Objaśnienia do Szczegótowej Mapy Geologicznej Polski w skali 1:50000 Arkusz Pita [Explanations to the Detailed Geological Map of Poland, scale 1:50000. Sheet Piła]. Polish Geological Institute, Warszawa, 50 pp.

Bartholomäus, W.A. \& Granitzki, K., 2004. Die Quarzsand-Lagerstätte Neubrandenburg-Fritscheshof - ein Fenster in die Ablagerungsverhältnisse zur Tertiärzeit. Neubrandenburger Geologische Beiträge 4, 49-66.

Bennett, M.R., Huddart, D. \& McCormick, T., 2000. An integrated approach to the study of glaciolacustrine landforms and sediments: a case study from Hagavatn, Iceland. Quaternary Science Reviews 19, 633-665.

Billi, P., Magi, M. \& Sagri, M., 1991. Pleistocene lacustrine fan delta deposits of the Valdarno Basin, Italy. Journal of Sedimentary Petrology 61, 280-290.

Blair, T.C., 1999. Cause of dominance by sheetflood vs. debris-flow processes on two adjoining alluvial fans, Death Valleys, California. Sedimentology 46, 10151028.

Blair, T.C. \& McPherson, J.G., 1994. Alluvial fans and their natural distinction from rivers based on morphology, hydraulic processes, sedimentary processes, and facies assemblages. Journal of Sedimentary Research 64, 450-489.
Boothroyd, J. C. \& Nummedal, D., 1978. Proglacial braided outwash: a model for humid alluvial-fan deposits. [In:] Miall, A.D. (Eds): Fluvial Sedimentology. Canadian Society of Petroleum Geologists, Memoir 5, 641-668.

Böse, M. \& Górska, M., 1995. Lithostratigraphical studies in the outcrop at Ujście, Torun Eberswalde Pradolina, western Poland. Eiszeitalter und Gegenwart 45, 1-14.

Cailleux, A., 1942. Les actionnes éoliennes périglaciaires en Europe. Mémoires de la Société Géologique de France 41, 176 pp.

Ciuk, E. \& Pożaryska, K., 1982. On paleogeography of the Tertiary of the Polish Lowland. Prace Muzeum Ziemi $35,81-88$.

Clemmensen, L.B. \& Houmark-Nielsen, M., 2008. Sedimentary features of a Weichselian glaciolacustrine delta. Boreas 10, 229-245.

Czubla, P., 2015. Eratyki fennoskandzkie w osadach glacjalnych Polski i ich znaczenie badawcze [Fennoscandian erratics in glacial sediments of Poland and their research significance]. Łódź University Press, 331 pp.

Czubla, P., Gałązka, D. \& Górska, M., 2006. Eratyki przewodnie w glinach morenowych Polski [Fennoscandian indicator erratics in glacial tills of Poland]. Przeglad Geologiczny 54, 352-362.

Folk, R.L. \& Ward, W.C., 1957. A study in the significance of grain-size parameters. Journal of Sedimentary Petrology 27, 3-26.

French, H.M., 2017. The Periglacial Environment. Fourth Edition. Wiley, $544 \mathrm{pp}$.

Galon, R., 1961. Morphology of the Noteć-Warta (or Torun-Eberswalde) ice marginal streamway. Prace Geograficzne 29, 7-115.

Górska-Zabielska, M., 2008. Obszary macierzyste skandynawskich eratyków przewodnich osadów ostatniego zlodowacenia północno-zachodniej Polski i północno-wschodnich Niemiec [Source regions of the Scandinavian erratics in Vistulian glacial deposits from NW Poland and NE Germany]. Geologos 14, 177-194.

Gruszka, B., Goździk, J. \& Zieliński, T., 2004. Osady delty i jeziora ze zlodowacenia warty oraz warunki ich sedymentacji (odsłonięcie bełchatowskie) [Delta and lake deposits and depositional conditions from the Warthanian (Bełchatów study site]. [In:] Harasimiuk, M. \& Terpiłowski, S. (Eds): Zlodowacenie warty w Polsce [Warthanian in Poland]. UMCS Press, Lublin, 71-86.

Harvey, A.M., Silva, P.G., Mather, A.E., Goy, J.L., Stokes, M. \& Zazo, C., 1999. The impact of Quaternary sea-level and climatic changes on coastal alluvial fans in the Cabo de Gate ranges, southeast Spain. Geomorphology 28, 1-22.

Hornung, J.J., Asprion, U. \& Winsemann, J. 2007. Jet-efflux deposits of a subaqueous ice-contact fan, glacial Lake Rinteln, northwestern Germany. Sedimentary Geology 193, 167-192.

Kasprzak L. \& Kozarski S., 1985. Litostratygraficzne podstawy subfazy chodzieskiej ostatniego zlodowacenia w północnej Wielkopolsce (wiadomość wstępna) [Lithostratigraphy of Chodzież subphase of the last glaciation in N Wielkopolska (preliminary results)]. Sprawozdania Poznańskiego Towarzystwa Przyjaciót 
Nauk za r. 1983. Wydział Matematyczno-Przyrodniczy 101, 51-57.

Kenig, K., 2004. Zróżnicowanie petrograficzne i mineralne równowiekowych glin morenowych z wybranych obszarów Niżu Polskiego [Petrographic and mineralogical diversity of the same age tills in the selected areas of the Polish Lowlands]. Przeglad Geologiczny 52, 325.

Kirkby, M.J., 1987. General models of long-term slope evolution through mass movements. [In:] Anderson, M. \& Richards, K. (Eds): Slope Stability, Geotechnical Engineering and Geomorphology. Wiley, London, 359379.

Kostaschuk, R.A. \& Smith, D.G., 1983. Late Quaternary lacustrine and deltaic sedimentation near Banff, Alberta. Canadian Journal of Earth Sciences 20, 1834-1842.

Kozarski, S. \& Kasprzak, L., 1987. Facies analysis and depositional models of Vistulian ice-marginal features in northwestern Poland [In:] Gardiner, V. (Ed.): International Geomorphology Part II. John Wiley and Sons, Chichester, 693-710.

Kozarski, S. \& Nowaczyk, B., 1985. Stratygrafia osadów pleistoceńskich w profilu Ujście nad Notecią (wiadomość wstępna) [Stratigraphy of Pleistocene sands in Ujście (preliminary results)]. Sprawozdania Poznańskiego Towarzystwa Przyjaciót Nauk za r. 1983. Wydziat Matematyczno-Przyrodniczy 101, 49-51.

Krüger, J. \& Kjær, K.H., 1999. A data chart for field description and genetic interpretation of glacial diamicts and associated sediments - with examples from Greenland, Iceland, and Denmark. Boreas 28, 386-402.

Lemons, D.R. \& Chan, M.A., 1999. Facies architecture and sequence stratigraphy of fine-grained lacustrine deltas along the Eastern margin of Late Pleistocene Lake Bonneville, Northern Utah and Southern Idaho. American Association of Petroleum Geologists Bulletin 83, 635-665.

Lønne, I. \& Nemec, W., 2004. High-arctic fan delta recording deglaciation and environment disequilibrium. Sedimentology 51, 553-589.

Lunkka, J. P. \& Alhonen, P., 1996. The development of a late Weichselian - early Holocene subaqueous ice-contact fan, Teikangas, SW Finland. Bulletin of the Geological Society of Finland 68, 34-49.

Lüthgens, C., Böse, M. \& Preussner, F., 2011. Age of the Pomeranian ice marginal position in northeastern Germany determined by Optically Stimulated Luminescence (OSL) dating of glaciofluvial sediments. Boreas 40, 598-615.

Marcinkowski, B. \& Mycielska-Dowgiałło, E., 2013. Heavy-mineral analysis in Polish investigations of Quaternary deposits: a review. Geologos 19, 5-23.

Marks, L., 2012. Timing of the Late Vistulian (Weichselian) glacial phases in Poland. Quaternary Science Reviews $44,81-88$.

Marks, L., Dzierżek, J., Janiszewski, R., Kaczorowski, J., Lindner, L., Majecka, A., Makos, M., Szymanek, M., Tołoczko-Pasek, A. \& Woronko, B., 2016. Quaternary stratigraphy and palaeogeography of Poland. Acta Geologica Polonica 66, 403-427.
McGowen, J.H. \& Garner, L.E., 1970. Physiographic features and stratification types of coarse grained point bars: modern and ancient examples. Sedimentology 14, 77-111.

Miall, A.D., 1996. The Geology of Fluvial Deposits. Sedimentary Facies, Basin Analysis, and Petroleum Geology. Springer, Berlin, 582 pp.

Mleczak, M., Pisarska-Jamroży, M., Van Loon, A.J. \& Roman, M., 2017. Seria złożowa plejstoceńskich piasków szklarskich w Ujściu - geneza, wiek i warunki sedymentacji [Pleistocene sands in Ujście - origin, age and depositional conditions]. Stratygrafia Plejstocenu Polski - Czwartorzęd pogranicza niżu i wyżyn w Polsce Środkowej [conference abstract].

Moskalewicz, D., Sokołowski, R.J. \& Fedorowicz, S., 2016. River response to climate and sea level changes during the late Saalian/Early Eemian in northern Poland - a case study of meandering river deposits in the Chłapowo cliff section. Geologos 22, 1-14.

Mycielska-Dowgiałło, E. \& Woronko, B., 1998. Analiza obtoczenia i zmatowienia powierzchni ziarn kwarcowych frakcji piaszczystej i jej wartość interpretacyjna [Rounding and frosting analysis of quartz sand-grain surfaces and their significance for interpretations]. Przegląd Geologiczny 46, 1275-1281.

Nilsen, T.H., 1985. Modern and ancient alluvial fan deposits. Van Nostrand Reinhold, New York, 372 pp.

Orton, G.J. \& Reading, H.G., 1993. Variability of deltaic processes in terms of sediment supply, with particular emphasis on grain size. Sedimentology 40, 475-512.

Passega, R., 1964. Grain size representation by CM patterns as a geological tool. Journal of Sedimentary Petrology 34, 830-847.

Pettersson, G., 1997. Unexpected ice movement directions during the last deglaciation in Ujście, NW Poland Stratigraphical investigations. Quaternary Studies in Poland 14, 85-94.

Pisarska-Jamroży, M., 2006. Transitional deposits between end-moraine and sandur plain in the Pomeranian glaciomarginal zone of NW Poland: a missing component of ice-contact sedimentary models. Boreas 35, 126-141.

Pisarska-Jamroży, M., 2008. Zonation of glaciomarginal environment inferred from Pleistocene deposits of Mysliborz Lakeland, NW Poland. Geografiska Annaler 90, 237-249.

Pisarska-Jamroży, M., 2015. Factors controlling sedimentation in the Torun-Eberswalde ice-marginal valley during the Pomeranian phase of Weichselian glaciation: an overview. Geologos 21, 1-29.

Pisarska-Jamroży, M. \& Zieliński, T., 2014. Pleistocene sandur rhythms, cycles and megacycles: Interpretation of depositional scenarios and palaeoenvironmental conditions. Boreas 43, 330-348.

Pisarska-Jamroży, M., Van Loon, A.J., Mleczak, M. \& Roman, M., 2019a. Enigmatic gravity-flow deposits at Ujście (W Poland), triggered by earthquakes (as evidenced by seismites) due to Saalian glacio-isostatic crustal rebound. Geomorphology 326, 239-251.

Pisarska-Jamroży, M., Belzyt, S., Bitinas, A., Jusienè, A. \& Woronko, B., 2019b. Seismic shocks, periglacial condi- 
tions and glaciotectonics as causes of the deformation of a Pleistocene meandering river succession in central Lithuania. Baltica 32, 63-77.

Piwocki, M., 1978. Warunki geologiczne i perspektywy wykorzystania złoża węgla brunatnego w rejonie Nakła nad Notecią [Geological setting and perspectives of use of brown coal deposits from the Nakło region upon Noteć River]. Przegląd Geologiczny 26, 584-588.

Piwocki, M. \& Ziembińska-Tworzydło, M., 1997. Neogene of the Polish Lowlands - lithostratigraphy and pollen-spore zones. Geological Quarterly 41, 21-40.

Rachocki, A.H. \& Church, M., 1990. Alluvial Fans: A Field Approach. Wiley, New York, 391 pp.

Ravier, E., Buoncristiani, J.-F., Clerc, S., Guiraud, M., Menzies, J. \& Portier, E., 2014. Sedimentological and deformational criteria for discriminating subglaciofluvial deposits from subaqueous ice-contact fan deposits: A Pleistocene example (Ireland). Sedimentology 61, 1382-1410.

Reineck, H.E. \& Singh, I.B.,1980. Depositional Sedimentary Environments. Springer-Verlag, New York, 549 pp.

Romanek, A., 2010. Węglanowość, obtoczenie ziaren i minerały ciężkie w formacjach Paleogenu i Neogenu środkowozachodniej Polski [Carbonate content, grain roundness and heavy minerals in Paleogene and Neogene formations of middle west Poland]. Biuletyn Państwowego Instytutu Geologicznego 438, 123-136.

Salamon, T. \& Wójcik, A., 2010. Development of a fore-mountain alluvial fan of the Olza River (southern Poland) during the Pleistocene. Annales Societatis Geologorum Poloniae 80, 39-52.

Sambrook Smith, G.H., Ashworth, P.J., Best, J.L., Woodward, J., \& Simpson, C.J., 2006. The sedimentology and alluvial architecture of the sandy braided South Saskatchewan River, Canada. Sedimentology 53, 413434

Schwietzer, G. \& Niedermeyer, R.-O., 2005. Fluviatiles Ablagerungsmilieu der untermiozanen Quarzsande von Fritscheshof (Neubranbenburg, Mecklenburg-Vorpommern). Neubrandenburger Geologische Beiträge 5, 47-60.

Singh, I.B., 1977. Bedding structures in a channel sand bar of the Ganga River near Allahabad, Uttar Pradesh, India. Journal of Sedimentary Petrology 47, 747-752.

Sokołowski, R.J., Janowski, Ł., Hrynowiecka, A. \& Molodkov, A., 2019. Evolution of fluvial system during the Pleistocene warm stage (MIS 7) - A case study from the Błądzikowo Fm., N Poland. Quaternary International 501, 1-11.

Thrasher, I. M., Mauz, B., Chiverrell, R.C. \& Lang, A., 2009. Luminescence dating of glaciofluvial deposits: A review. Earth-Science Reviews, 97, 133-146.

Toonen, W.H., Kleinhans, M.G. \& Cohen, K.M., 2012. Sedimentary architecture of abandoned channel fills. Earth Surface Processes \& Landforms 37, 459-472.

Udden, J.A., 1914. Mechanical composition of clastic sediments. Geological Society of America Bulletin 25, 655744 .
Wentworth, C.K., 1922. A scale of grade and class terms for clastic sediments. The Journal of Geology 30, 377392.

Winsemann, J., Meyer, T., Asprion, U. \& Schramm, C., 2007. Facies characteristics of Middle Pleistocene (Saalian) ice-margin subaqueous fan and delta deposits, glacial Lake Leine, NW Germany. Sedimentary Geology 193, 105-129.

Winsemann, J., Hornung, J.J., Meinsen, J., Asprion, U., Polom, U., Brandes, C., Bussmann, M. \& Weber, C., 2009. Anatomy of a subaqueous ice-contact an and delta complex, Middle Pleistocene, North-west Germany. Sedimentology 56, 1041-1076.

Woronko, B., Pisarska-Jamroży, M. \& van Loon, A.J., 2015. Reconstruction of sediment provenance and transport processes from the surface textures of quartz grains from Late Plaistocene sandurs and an ice-marginal valley in NW Poland. Geologos 21, 105-115.

Woźniak, P.P. \& Pisarska-Jamroży, M., 2018. Debris flows with soft-sediment clasts in a Pleistocene glaciolacustrine fan (Gdańsk Bay, Poland). Catena 165, 178-191.

Woźniak, P.P., Pisarska-Jamroży, M. \& Elwirski, Ł., 2018. Orientation of gravels and soft-sediment clasts in subaqueous debrites - implications for palaeodirection reconstruction: case study from Puck Bay, northern Poland. Bulletin of the Geological Society of Finland 90, 161-174.

Zieliński, P., Sokołowski, R.J., Fedorowicz, S., Woronko, B., Hołub, B., Jankowski, M., Kuc, M. \& Tracz, M., 2016. Depositional conditions on an alluvial fan at the turn of the Weichselian to the Holocene - a case study in the Żmigród Basin, southwest Poland. Geologos 22, 105-120.

Zieliński, T., 1993. Sandry Polski północno-wschodniej: osady i warunki sedymentacji. [Sandurs of north-eastern Poland: sediments and depositional conditions]. Prace Naukowe Uniwersytetu Ślaskiego w Katowicach 1398, Uniwersytet Śląski, 95 pp.

Zieliński, T., 1998. Litofacjalna identyfikacja osadów rzecznych [Lithofacial identification of river deposits]. [In:]: Mycielska-Dowgiałło, E. (Ed.): Struktury sedymentacyjne $i$ postsedymentacyjne $w$ osadach czwartorzędowych $i$ ich wartość interpretacyjna [Sedimentary and postsedimentary structures in Quaternary deposits and their interpretation value]. Warsaw University Press, 195-260.

Zieliński, T., 2014. Sedymentologia. Osady rzek i jezior [Sedimentology. Deposits of rivers and lakes]. Wydawnictwo Naukowe UAM, Poznań, 594 pp.

Zieliński, T. \& Pisarska-Jamroży, M., 2012. Jakie cechy litologiczne warto kodować a jakie nie? [Which features of deposits should be included in a code and which not?]. Przeglad Geologiczny 60, 387-397.

Zwahr, H., 2001. Der Quarzsand Neubrandenburg und seine Werkstoffeigenschaften. Neubrandenburger Geologische Beiträge, Sonderband, 45-54.

Manuscript received: 18 April 2019 Revision accepted: 10 July 2019 